The International Journal of
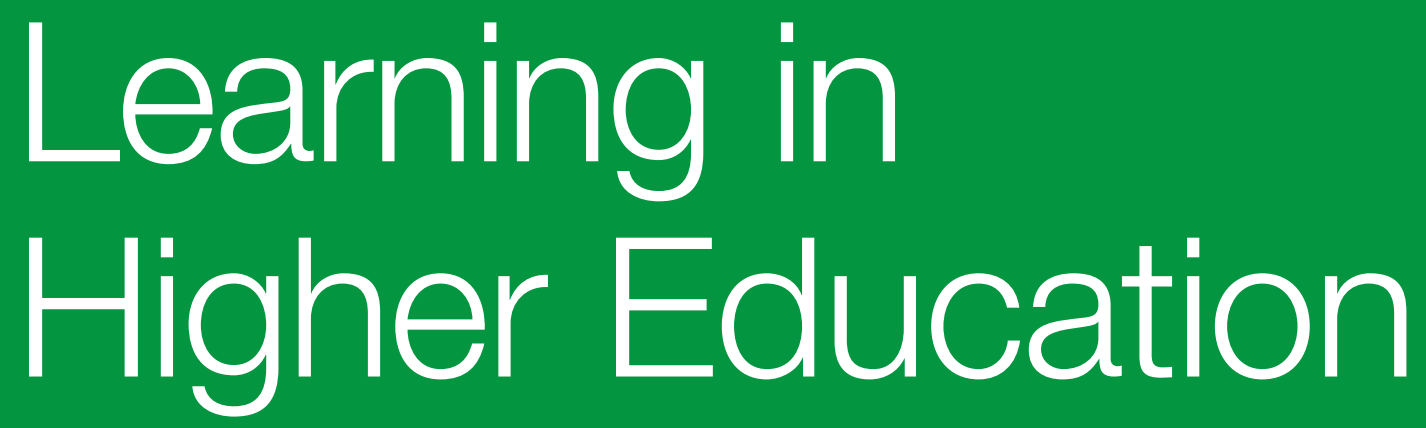

Mobile Devices for Literary Education in Teacher Training

An Innovative Experience with M-Learning 
THE INTERNATIONAL JOURNAL OF LEARNING IN HIGHER EDUCATION http://thelearner.com

ISSN: 2327-7955 (Print)

ISSN: 2327-8749 (Online)

http://doi.org/10.18848/2327-7955/CGP (Journal)

First published by Common Ground Research Networks in 2018 University of Illinois Research Park

2001 South First Street, Suite 202

Champaign, IL 61820 USA

$\mathrm{Ph}:+1-217-328-0405$

http://cgnetworks.org

The International Journal of Learning in Higher Education is a peer-reviewed, scholarly journal.

\section{COPYRIGHT}

(C) 2018 (individual papers), the author(s)

(C) 2018 (selection and editorial matter)

Common Ground Research Networks

\section{(이 $\$$}

Some Rights Reserved.

Public Licensed Material: Available under the terms and conditions of the Creative Commons Attribution-NonCommercial-NoDerivatives 4.0 International Public License (CC BY-NC-ND 4.0). The use of this material is permitted for non-commercial use provided the creator(s) and publisher receive attribution. No derivatives of this version are permitted. Official terms of this public license apply as indicated here: https://creativecommons.org/licenses/by-nc-nd/4.0/legalcode

\section{Crossref}

\section{EDITORS}

Bill Cope, University of Illinois, USA

Mary Kalantzis, University of Illinois, USA

\section{HEAD OF JOURNAL PRODUCTION}

McCall Macomber, Common Ground Research Networks, USA

\section{EDITORIAL ASSISTANT}

Crystal Lasky Robinson, Common Ground Research Networks, USA

\section{ADVISORY BOARD}

The Learner Research Network recognizes the contribution of many in the evolution of the Research Network. The principal role of the Advisory Board has been, and is, to drive the overall intellectual direction of the Research Network. A full list of members can be found at http://thelearner.com/about/advisory-board.

\section{PEER REVIEW}

Articles published in The International Journal of Learning in Higher Education are peer reviewed using a two-way anonymous peer review model. Reviewers are active participants of The Learner Research Network or a thematically related Research Network. The publisher, editors, reviewers, and authors all agree upon the following standards of expected ethical behavior, which are based on the Committee on Publication Ethics (COPE) Codes of Conduct and Best Practice Guidelines. More information can be found at: http://thelearner.com/journals/model.

\section{ARTICLE SUBMISSION}

The International Journal of Learning in Higher Education publishes quarterly (March, June, September, December). To find out more about the submission process, please visit $\mathrm{http}: / /$ thelearner.com/journals/call-for-papers.

\section{ABSTRACTING AND INDEXING}

For a full list of databases in which this journal is indexed, please visit http://thelearner.com/journals/collection.

\section{RESEARCH NETWORK MEMBERSHIP}

Authors in The International Journal of Learning in Higher Education are members of The Learner Research Network or a thematically related Research Network. Members receive access to journal content. To find out more, visit http://thelearner.com/about/become-a-member.

\section{SUBSCRIPTIONS}

The International Journal of Learning in Higher Education is available in electronic and print formats. Subscribe to gain access to content from the current year and the entire backlist. Contact us at support@cgnetworks.org.

\section{ORDERING}

Single articles and issues are available from the journal bookstore at https://cgscholar.com/bookstore.

\section{HYBRID OPEN ACCESS}

The International Journal of Learning in Higher Education is Hybrid Open Access, meaning authors can choose to make their articles open access. This allows their work to reach an even wider audience, broadening the dissemination of their research. To find out more, please visit http://thelearner.com/journals/hybrid-open-access.

\section{DISCLAIMER}

The authors, editors, and publisher will not accept any legal responsibility for any errors or omissions that may have been made in this publication. The publisher makes no warranty, express or implied, with respect to the material contained herein. 


\title{
Mobile Devices for Literary Education in Teacher Training: An Innovative Experience with M-Learning
}

\author{
María del Rosario Neira-Piñeiro, ${ }^{1}$ University of Oviedo, Spain
}

\begin{abstract}
The emergence of mobile devices has piqued researchers' interest in the educational possibilities of these electronic tools. This work, using a case-study methodology, presents an innovative project with m-learning focused on literary education in higher education. The project—creating a video review of a children's book-was carried out with sixty-eight students majoring in early childhood education. To evaluate the effectiveness of this project, the final tasks were considered together with the instructor's and students' perception. An instrument was designed to analyse the videos, and two questionnaires were distributed to elicit students' and instructor's perceptions. Findings reveal the flexibility of m-learning and its adequacy for literary education in teacher training. The students learned to select and evaluate children's books and acquired some knowledge of children's literature. The task involved searching for information, critical thinking, analysis and synthesis, decision-making, autonomy, development of communicative competence, creativity, and teamwork skills and helped to familiarise students with m-learning. Finally, weaknesses detected suggest that more taught sessions are required and that more attention should be paid to oral skills. Besides, it is necessary to incentivize the use of the task blog and to foster social interaction.
\end{abstract}

Keywords: E-Learning, M-Learning, Higher Education, Teacher Training, Children 's Literature

\section{Introduction}

$\mathrm{T}$ The growing popularity and technological development of mobile devices has generated considerable interest in the potential uses of such technology in education, leading to the appearance of mobile learning (Crescente and Lee 2011; Gros 2013; Sevillano 2013; Sevillano and Vázquez-Cano 2015; Wu et al. 2012). From a technocentric perspective (Castaño and Cabero 2013), this can be understood as learning supported by mobile devices while, from an educational point of view, more emphasis is placed on characteristics such as mobility and ubiquity. The educational interest of mobile devices lies in some of its characteristics (Brazuelo and Gallego 2011; Castaño and Cabero 2013; Crescente and Lee 2011; Gros 2013; Luque-Agulló and Martos-Vallejo 2015; Miangah and Nezarat 2012; Ramos, Herrera, and Ramírez 2010; Sevillano 2013; Wu et al. 2012). Firstly, affordability, wireless connectivity and multiple performance features and applications make them accessible and suitable for searching for information, listening to music, taking photographs and videos, communicating, accessing social networks, etc.

In addition, mobility and portability allow for both ubiquitous and asynchronous learning, that is, learning which takes place wherever and whenever. This affords freedom to the student, thereby fostering self-regulated learning. Mobile devices also support a more personalised, student-centred learning (Crescente and Lee 2011), which proves particularly suitable for informal learning. A further strength lies in connectivity and social interaction, which facilitates communicative activities and collaborative tasks, without requiring the physical presence of all participants. Thus, m-learning combines the advantages associated with e-learning with the flexibility afforded by mobile devices (Fombona and Pascual 2013). Furthermore, the generalisation of such devices together with their widespread use among young people justifies

\footnotetext{
${ }^{1}$ Corresponding Author: María del Rosario Neira-Piñeiro, Faculty of Education, C/ Aniceto Sela, s/n, Department of Education, University of Oviedo, Oviedo, 33005, Spain. email: neiramaria@uniovi.es
}

The International Journal of Learning in Higher Education

Volume 19, Issue 3, 2018, http://thelearner.com

(C) Common Ground Research Networks, María del Rosario Neira-Piñeiro,

Some Rights Reserved, (CC BY-NC-ND 4.0).

Permissions: support@cgnetworks.org

ISSN: 2327-7955 (Print) ISSN: 2327-8749 (Online)

http://doi.org/10.18848/2327-7955/CGP/v25i03/47-63 (Article) 
their introduction in the classroom, which cannot turn its back on reality (Brazuelo and Gallego 2011; Trujillo 2015; Castaño and Cabero 2013; Gros 2013). The positive attitude of young people toward mobile devices should also be considered, since this favours motivation (Atwel et al. 2009, quoted in Brazuelo and Gallego 2011; Ireri, Wario, and Mwingirwa 2018; Ramos, Herrera, and Ramírez 2010).

However, there are certain drawbacks and obstacles that make it difficult to fully implement m-learning. Brazuelo and Gallego (2011) find that its integration in the classroom is constrained by strict regulations, lack of student awareness, and insufficient teacher training. Moreover, mobile devices have certain disadvantages (small display screen, awkward keypad, limited battery life) and can also lead to lack of concentration and poor writing habits. Furthermore, there may also be certain risks stemming from inappropriate uses such as cyberbullying, sexting, addiction or the disclosure of personal information on the internet (Brazuelo and Gallego 2011; Miangah and Nezarat 2012).

Nevertheless, the benefits outweigh both the dangers and disadvantages, which might be addressed through appropriate strategies. It is essential to choose an appropriate instructional model and select technological resources that support the teaching-learning process. Instructors also should provide students with modelling, coaching, and scaffolding (Ireri, Wario, and Mwingirwa 2018).

M-learning is particularly applicable to a flexible model of teaching that is student-centred and can be easily integrated into either face-to-face or hybrid teaching or be combined with other on-line learning activities (Delgado 2014). Although best suited to distance learning, it can also be used to carry out collaborative tasks in the classroom, as it offers more mobility and possibilities of interaction than computer-based learning (Miangah and Nezarat 2012). Thanks to multiple functionalities and applications, mobile devices can be used to produce educational materials (Johnson, Smith, and Stone 2010), to communicate or to carry out learning activities (Trujillo 2015). In face-to-face learning, the aim is to make use of students' own devices, following the BYOD ("bring your own device") trend, thereby making students feel relaxed and encouraging them to take ownership of their learning (Johnson et al. 2016). There is current evidence of a variety of innovating experiences involving m-learning that have been carried out in various fields of knowledge, especially in language learning (Kukulska-Hulme 2009; LuqueAgulló and Martos-Vallejo 2015; Shohel and Power 2010), and at diverse levels of education from pre-primary to university (Brazuelo and Gallego 2011; Castaño and Cabero 2013; Giráldez 2015; Johnson, Smith, and Stone 2010; Nguyen, Barton, and Ngugyen 2015; Vázquez-Cano 2014).

M-learning is well suited to the characteristics of university students, who make intensive use of technology, multitask, know how to generate content, are permanently connected, enjoy active and creative tasks, are used to real-time communication, and feel comfortable when interacting on the internet (Sevillano 2013). In such a context, m-learning is more studentcentred; gives greater accessibility to, and creation of, content, whenever and wherever; is more suitable for out-of-class work; opens channels of communication and interaction; offers the possibility of cooperative work and contributes to learning through competences; etc. It also facilitates teamwork and provides support for students with disabilities. Finally, it affords an opportunity for updating teaching methodology in line with the European Higher Education Area (EHEA) framework (Al-Emran, Elsherif, and Shaalan 2016; Ally and Prieto-Blázquez 2014; Sevillano and Vázquez-Cano 2015). In this context, m-learning is particularly relevant for teacher training, as shown by some research on this topic (Ekanayake and Wishart 2015; García and Iglesias 2016; Herrington and Herrington 2006). However, teacher training regarding the use of m-learning requires further research, as investigations concerning this issue are limited (Sung, Chang and Liu 2016). Mobile technology is becoming increasingly important in universities around the world (Al-Emran, Elsherif, and Shaalan 2016). However, in some countries mlearning is still little used in university classrooms, requiring greater institutional support, 
resources, teacher training, positive teacher and learner attitudes, and student awareness if it is to become generalised (Burden and Hopkins 2016; Iqbal and Bhatti 2017; Chen et al. 2015; Sevillano and Vázquez-Cano 2015).

In the teaching of literature, there is growing interest in the opportunities offered by technological resources. Thus, researchers strongly recommend digital-based activities, which reproduce real reader practices such as discussing books on blogs or internet forums, sharing book reviews on YouTube, publishing literary texts on the internet, etc. (Caro-Valverde 2015; Margallo and Mata 2015; Lluch and Zayas 2015; Rovira-Collado 2017). However, although there are experiences and research focused on the use of ICT in teaching literature, $\mathrm{m}$-learning in literary education has been scarcely explored. Therefore, this paper aims to link two relevant areas of study. The first is m-learning in higher education, which still needs further research (Ally and Prieto-Blázquez 2014) - above all, about its application to teacher training (Baran 2014; Burden and Hopkins 2016). The second is the use of m-learning in the teaching of literature, which is the focus of the current research.

\section{Objectives of the Research}

This paper focuses on the application of mobile technologies to literary education. More specifically, it aims to analyse a project based on the use of mobile learning (m-learning) in higher education and to reflect on the potential of mobile devices in the literary training of preservice early childhood teachers. Finally, this study hopes to answer the following research questions by means of analysing one particular case:

- Can m-learning be successfully adapted to the context of teacher training in higher education?

- What possibilities does it offer for the literary education of future teachers?

- What are the main advantages and disadvantages of m-learning in this case?

\section{Methodology}

This work uses case-study methodology, adopting a mixed methodological qualitative and quantitative approach. According to Hitchcock and Hughes, "case studies are distinguished less by the methodologies that they employ than by the subjects/objects of their enquiries" (Hitchcock and Hughes 1995, quoted in Cohen, Manion, and Morrison 2005, 181). Case-study methodology is characterised by focusing on the study of a particular case (Denzin and Lincoln 1994), commonly addressing "a problem or an intervention of interest to the researcher's professional practice" (Harland 2014, 1116). It is widely used in social sciences, as it provides an exceptional way to understand educational phenomena (Bisquerra 2004). Case studies present several advantages that justify the selection of this method. As Nisbet and Watts point out (1984, quoted in Cohen, Manion, and Morrison 2005, 184), "the results are more easily understood by a wide audience," "they catch unique features that may otherwise be lost in larger scale data," and "they provide insights into other similar situations and cases." According to Adelman et al. (1990, quoted in Cohen, Manion, and Morrison 2005, 184), they are "strong on reality," allow for the complexity of social phenomena, and enable generalizations departing from the particular situation. In addition, case study "provides a unique example of real people in real situations, enabling readers to understand ideas more clearly than simply presenting them with abstract theories or principles. Indeed, a case study can enable readers to understand how ideas and abstract principles can fit together" (Cohen, Manion, and Morrison 2005, 181).

This work was undertaken as a case study because of the intrinsic interest of the experience due to the lack of both research and innovative experiences related to m-learning in undergraduate teachers' literary education. It was also considered that the analysis of this experience could provide some insightful arguments for innovation with m-learning in other 
similar contexts, namely the literary education of future teachers in higher education. To describe and analyse the experience and to evaluate its effectiveness, as well as to draw some educational implications, several tools were combined to collect the data: direct observation, a specific tool to analyse the final products, and two final questionnaires.

Case studies commonly provide a narrative description of the relevant events (Cohen, Manion, and Morrison 2005), so direct observation was used to provide a detailed description of the experience. The description of the experience is necessary to properly understand how it was organised and to provide a model that could be applied in other similar contexts. Secondly, the analysis of the final products created by the students was considered a crucial element, as it provided information on task achievement and the skills and knowledge involved. To carry out the analysis, an ad hoc instrument was designed assessing technical data, dissemination of videos on the internet, expressive techniques used, and content of the videos. Finally, as case study "focuses on individual actors or groups of actors and seeks to understand their perception of events" (Cohen, Manion, and Morrison 2005, 181), it was considered necessary to collect data about participants' (students and instructor) perceptions at the end of the experience. To discover students' perception, a ten-item questionnaire was designed and posted on the online campus to be completed by students once the experience was finished. Items related to difficulties encountered, learning outcomes, diffusion of videos and personal critique, using a variety of question types (multiple choice, a Likert-type scale with five options, and open-ended questions). A seven-item questionnaire elicited the instructor's perception. This second questionnaire included items related to student learning outcomes, student involvement, instructor's degree of satisfaction, and positive and negative aspects and suggestions for improving the experience. As in the students' questionnaire, several kinds of question types were used, including a Likert-type scale and open-ended questions.

\section{Sample}

The sample was composed of sixty-eight undergraduate students (sixty-five women and three men) studying early childhood education at the Faculty of Education of the University of Oviedo (Spain). All of them were taking the third-year course "Teaching Children's Literature," a mandatory course in this degree. The sample shows a predominance of woman, as usually happens in early childhood education programs in Spanish universities. As is common in future preschool teachers, these were vocational students who value practical instructional activities and are motivated by tasks they consider meaningful and applicable to their future profession (Fernández-Molina, González, and Del-Molino 2011). All the students involved had their own mobile devices, which they usually brought to the class and used for multiple purposes. It is also worth mentioning that they had all received prior training in educational technology during the first year of the degree.

\section{Context of the Study}

This experience was part of a broader project on m-learning, supported by the University of Oviedo and intended to promote methodological innovation in the degree of teacher training. It was noticeable that even though the students make frequent use of mobile devices, m-learning was not commonly used in the context of this study and was applied for the first time in the course on children's literature. The project was designed as a blended-learning collaborative task involving the creation of a video review of a work of children's literature and then sharing this on a blog set up on the Moodle platform. The audiovisual product was meant for other adult literary mediators and involved recommending a work that would stimulate interest in reading and encourage an initial contact with literature in early-years education.

The creation of video reviews is a kind of activity according to the current trends in literary education, which pays attention to creative tasks as a way of expressing the response to literature. 
Activities based on sharing books are also recommended, as they provide a social dimension to the reading practices (Margallo and Mata 2015). Moreover, the creation of video reviews, also known as bookTubers, and book trailers (videos clips promoting books) is considered an appropriate activity for literary education and to foster reading, as it combines reading and writing, contributes to digital and audiovisual competence, and is well-suited to collaborative work and project-based learning (Lluch and Zayas 2015; Rovira-Collado 2017). In this case, the process of audiovisual creation was designed on the model of the experience carried out by Ambròs (2014) but adapted to the m-learning approach and to the context of the course on children's literature.

In consonance with Ozdamli's (2012) pedagogical considerations, a constructivist approach was adopted and priority was given to collaborative work and the acceptance of responsibilities, with an active role being assigned to students. Face-to-face and online tasks were combined. Mobile technology was used to seek and transmit information as a means of creation and expression and as a tool for communication on a digital channel, using students' own devices, following the BYOD trend. The photographic, video, and audio recorder and player together with the web browser were used in addition to free applications for audio and video editing. We also set up a Moodle platform providing support materials and a blog on which to share the videos. The main teaching aims were to become familiar with m-learning in the context of literary education, apply knowledge of the course to the selection and evaluation of a literary work for children, and develop various competences through collaborative work supported by mobile technologies (Figure 1).

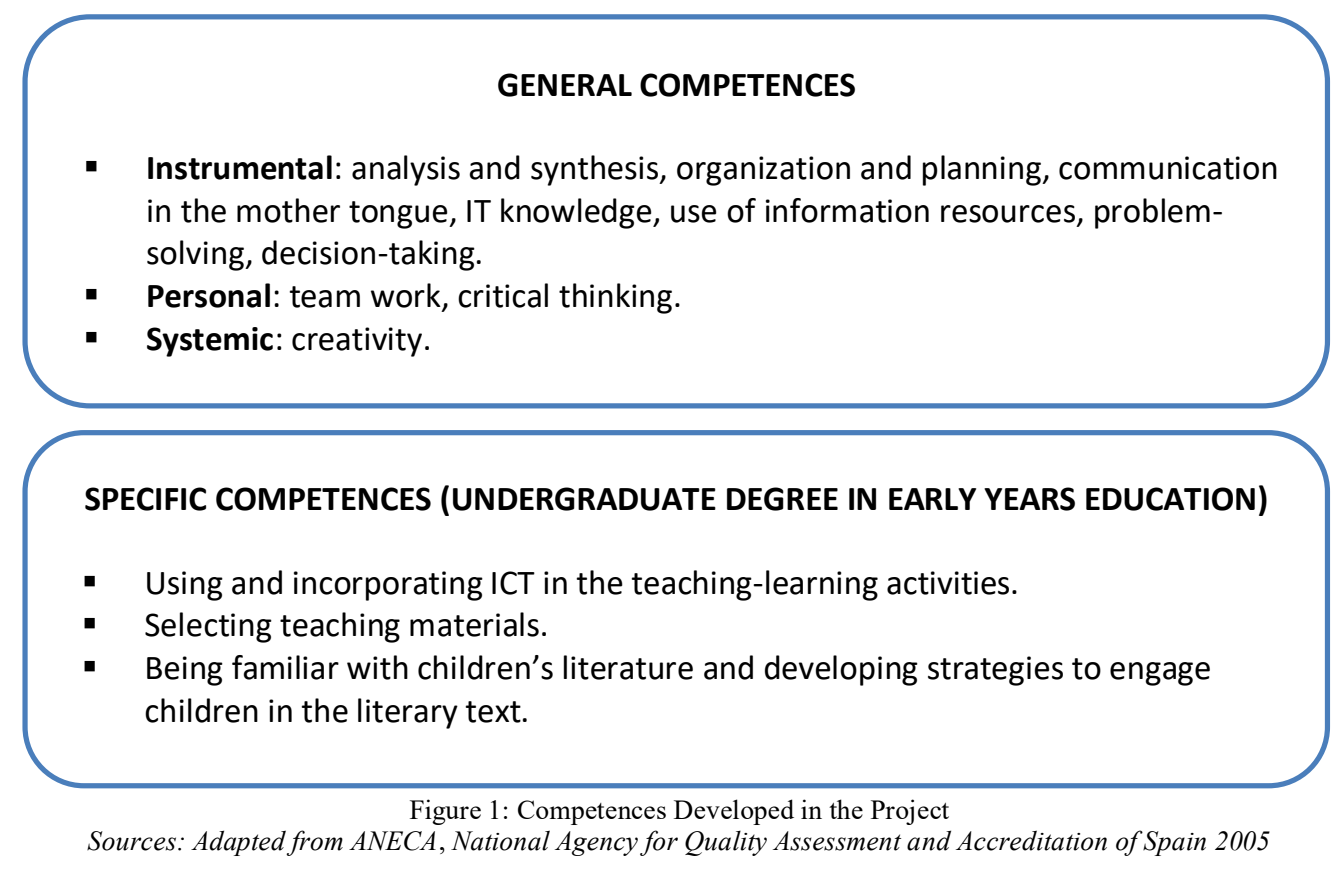

Five phases were established (Figure 2), including two face-to-face sessions and out-of-class work. Throughout the process, the students were supported by the teacher either directly in class or on-line via the Moodle platform. 


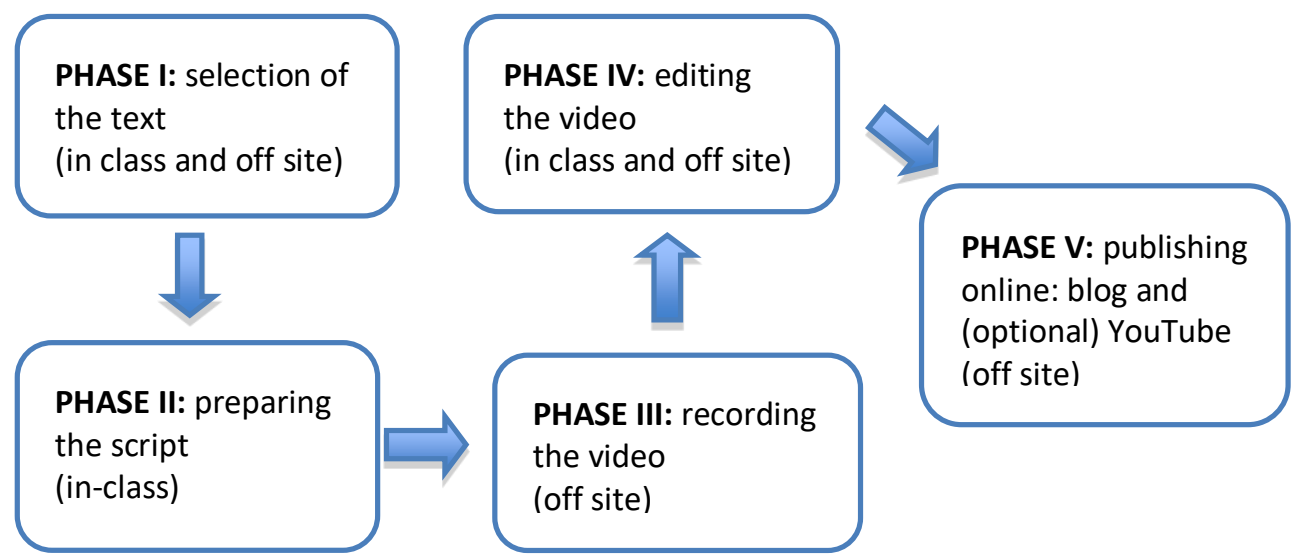

Figure 2: Phases

Source: Neira-Piñeiro 2018

Prior to starting work, the task was explained, support materials were uploaded to the Moodle platform, and students were shown several video reviews from the blog entitled "Kuentalibros." ${ }^{2}$ The students were asked to search for children's books they considered suitable for early-years education and bring in to the next session (Phase I). At the first in-class session, students were organised into twelve collaborative teams, each of which chose a literary work and wrote the script for their video review (end of Phase I). At the end of the class session, each team uploaded the script onto the Moodle platform so that the instructor could provide feedback with suggestions for improving the text (Phase II). The video was filmed out of class (Phase III) and was edited during the second in-class session using a video editing application for mobile devices (Phase IV). This phase was time-consuming, with the result that most teams finished editing out of class. Finally, each team shared their video review (Figure 3) on the blog created for the purpose on the Moodle platform (Phase V). In addition, students were encouraged to publish their videos on YouTube, although this was voluntary.

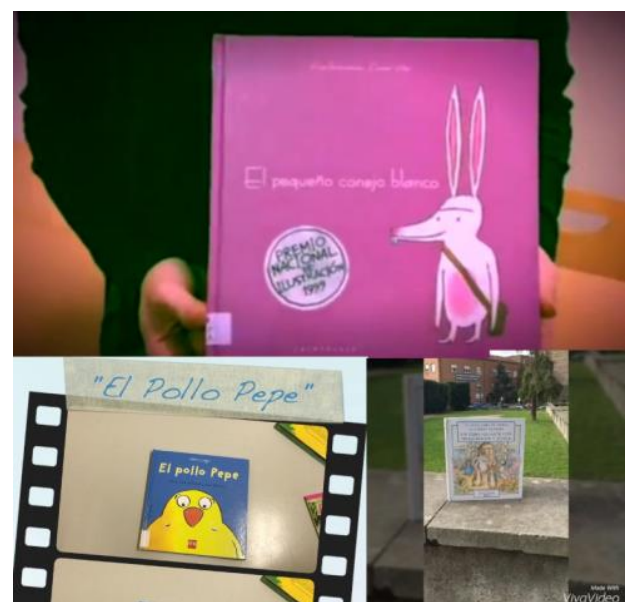

Figure 3. Three Examples of the Video Reviews ${ }^{3}$

Source: Videos created by the students. Images reproduced with the permission of the publishers.

\footnotetext{
${ }^{2}$ This blog can be accessed through http://kuentalibros.blogspot.com/.

${ }^{3}$ From top to down and left to right, these video reviews refer to the books: Nick Denchield and Ant Parker, El pollo Pepe [Charlie Chick] (Madrid: SM, 2014); Xosé Ballesteros and Óscar Villán, El pequeño conejo blanco [The Little White Rabbit] (Pontevedra: Kalandraka, 2006); Beatrix Potter, El gran libro de Perico, el conejo travieso [The Big Book of Peter, the Naughty Rabbit] (Barcelona: Debate, 1992).
} 


\section{Results}

\section{Final Products}

The students produced twelve short video reviews (Table 1) mostly made with smartphones using Android operating systems (58.3\%), although they also used iPads (33\%) and one team combined two different devices (iPhone to record the video and iPad to edit it). The application that most students chose was VivaVideo ( $41.7 \%$ of the video reviews), followed by iMovie (33.3\%), while two teams opted for Windows Live Movie Maker for Android and Video Show, respectively. One team encountered technical difficulties with the applications and as a result carried out the editing online. Of these, 41.7 percent shared their review on YouTube, while 58.3 percent chose not to do so, uploading their video reviews to the subject blog where it was only visible to their classmates and the lecturer.

Table 1: Technical Specifications and Publication on the Internet

\begin{tabular}{|l|l|l|l|l|}
\hline Video & Length & Device & Application & On YouTube \\
\hline V1 & 2' $15^{\prime}$, & Smartphone & Windows Live Movie Maker & Yes \\
\hline V2 & 2'52', & Smartphone & Viva Video & Yes \\
\hline V3 & 1'58', & iPhone, iPad & iMovie & No \\
\hline V4 & 1'48', & iPad & iMovie & No \\
\hline V5 & 2' 45', & iPad (recording) & Online editing & Yes \\
\hline V6 & 1'21', & Smartphone & VideoShow & No \\
\hline V7 & 2' & Smartphone & VivaVideo & Yes \\
\hline V8 & 1' 3', & Smartphone & VivaVideo & No \\
\hline V9 & 1'18'’ & iPad & iMovie & No \\
\hline V10 & 2'02'’ & iPad & iMovie & Yes \\
\hline V11 & 1' $18^{\prime}$, & Smartphone & VivaVideo & No \\
\hline V12 & 2' $20^{\prime}$, & Smartphone & VivaVideo & No \\
\hline
\end{tabular}

Regarding the expressive techniques used (Table 2), video image and the spoken word were given priority. All reviews showed images of the book recommended and used oral discourse to provide information about the work. Of these, 75 percent used voiceover, while 58 percent were created by the students themselves talking on camera; 83.3 percent of the videos made use of written language (captions) to indicate the reference, add the credits, or include titles or section headings. More than half (66.7\%) used music to open, close, or develop the review.

Interestingly, 83.3 percent chose interior settings, of which 41.7 percent corresponded to the Faculty of Education itself, in some cases adding props such as a desk with children's books, etc. Additionally, 25 percent were located in neutral settings in which there was hardly any description of the spatial context, and 16.7 percent used exterior settings located in green areas in consonance with the natural space in which the chosen stories were framed. Lastly, visual and sound effects were used as were still images, choreography, dramatisation, puppets and dolls, always in line with the content of the review. 
THE INTERNATIONAL JOURNAL OF LEARNING IN HIGHER EDUCATION

Table 2: Expressive Elements

\begin{tabular}{|c|c|c|c|c|c|c|c|}
\hline Video & $\begin{array}{l}\text { Pictures } \\
\text { from the } \\
\text { book }\end{array}$ & Voiceover & $\begin{array}{l}\text { Camera } \\
\text { presentation }\end{array}$ & Music & Captions & Setting & Others \\
\hline$V 1$ & Yes & Yes & Yes & No & Yes & Neutral & $\begin{array}{l}\text { Photography, soft } \\
\text { toy, visual effects }\end{array}$ \\
\hline$V 2$ & Yes & Yes & Yes & Yes & Yes & $\begin{array}{l}\text { Classroom } \\
\text { Interior } \\
\end{array}$ & Text on blackboard \\
\hline$V 3$ & Yes & Yes & No & Yes & Yes & Campus garden & Camera movement \\
\hline$V 4$ & Yes & No & Yes & No & Yes & Park & $\begin{array}{l}\text { Dramatization, } \\
\text { masks, still image, } \\
\text { visual effects }\end{array}$ \\
\hline$V 5$ & Yes & Yes & No & Yes & Yes & $\begin{array}{l}\text { Classroom } \\
\text { interior }\end{array}$ & $\begin{array}{l}\text { Dramatization, } \\
\text { puppets, } \\
\text { blackboard, } \\
\text { dialogues, video } \\
\text { introduction, visual } \\
\text { effects }\end{array}$ \\
\hline V6 & Yes & Yes & No & No & Yes & Neutral & Visual effects \\
\hline$V 7$ & Yes & Yes & Yes & Yes & Yes & $\begin{array}{l}\text { Classroom } \\
\text { interior }\end{array}$ & $\begin{array}{l}\text { Video introduction, } \\
\text { visual effects, set } \\
\text { design }\end{array}$ \\
\hline$V 8$ & Yes & No & Yes & No & Yes & $\begin{array}{l}\text { House } \\
\text { interior }\end{array}$ & $\begin{array}{l}\text { Visual and sound } \\
\text { effects, soft toys }\end{array}$ \\
\hline$V 9$ & Yes & Yes & No & Yes & Yes & Neutral & \\
\hline V10 & Yes & Yes & No & Yes & Yes & $\begin{array}{l}\text { Classroom } \\
\text { interior }\end{array}$ & $\begin{array}{l}\text { Videos, introduction } \\
\text { and transition }\end{array}$ \\
\hline$V 11$ & Yes & Yes & Yes & Yes & No & Faculty interior & $\begin{array}{l}\text { Visual effects, } \\
\text { dance }\end{array}$ \\
\hline$V 12$ & Yes & No & Yes & Yes & No & Faculty interior & Mural \\
\hline
\end{tabular}

Source: Neira-Piñeiro 2018

Finally (Table 3), students selected a variety of works, most of which were picture books, covering topics such as animals, family, love, fear, death, etc. All the reviews gave information on the content of the book regarding the storyline, theme, and characters; the author and illustrator; and other details (awards, dissemination and sales, etc.). Some videos included an analysis of the illustrations and/or their relationship with the verbal language. All of them justified the work's educational interest from the point of view of the characteristics of the images, features of the verbal discourse, theme, the book's ludic dimension, or its learning potential. As a final detail, 33.3 percent included a reading of an extract from the book. 
NEIRA-PIÑEIRO: MOBILE DEVICES FOR LITERARY EDUCATION IN TEACHER TRAINING

Table 3: Content of the Videos

\begin{tabular}{|c|c|c|c|c|}
\hline Video & Type of work & Topic & Information & Extract \\
\hline$V 1$ & Picture book & $\begin{array}{l}\text { Family, adventure, movement, } \\
\text { space }\end{array}$ & $\begin{array}{l}\text { Content } \\
\text { Origin of text } \\
\text { Image analysis } \\
\text { Author / illustrator } \\
\text { Educational interest }\end{array}$ & No \\
\hline$V 2$ & Picture book & $\begin{array}{l}\text { Dangers, traditional story } \\
\text { characters }\end{array}$ & $\begin{array}{l}\text { Content } \\
\text { Text-image relationship } \\
\text { Author / illustrator } \\
\text { Additional details } \\
\text { Educational interest }\end{array}$ & Yes \\
\hline$V 3$ & Pop-up book & Animals & $\begin{array}{l}\text { Book characteristics } \\
\text { Author } \\
\text { Educational interest }\end{array}$ & No \\
\hline$V 4$ & Picture book & Animals, survival, grit, family & $\begin{array}{l}\text { Content } \\
\text { Image analysis } \\
\text { Additional details } \\
\text { Author / illustrator } \\
\text { Educational interest }\end{array}$ & No \\
\hline$V 5$ & $\begin{array}{l}\text { Educational } \\
\text { story }\end{array}$ & Toilet training & \begin{tabular}{|l} 
Content \\
Educational interest
\end{tabular} & No \\
\hline V6 & Picture book & Diversity, tolerance & $\begin{array}{l}\text { Content } \\
\text { Visual influences } \\
\text { Author } \\
\text { Educational interest }\end{array}$ & No \\
\hline$V 7$ & Pop-up book & $\begin{array}{l}\text { Mother-child bond, animals, } \\
\text { nutrition, body }\end{array}$ & $\begin{array}{l}\text { Content } \\
\text { Author / illustrator } \\
\text { Additional details } \\
\text { Educational interest } \\
\end{array}$ & Yes \\
\hline$V 8$ & Picture book & Expression of affection & \begin{tabular}{|l} 
Content \\
Author / illustrator \\
Educational interest \\
\end{tabular} & No \\
\hline V9 & Picture book & Death, grief & $\begin{array}{l}\text { Content } \\
\text { Author } \\
\text { Additional details } \\
\text { Educational interest } \\
\end{array}$ & No \\
\hline$V 10$ & Picture book & Animals, fear, courage & $\begin{array}{l}\text { Content } \\
\text { Origin of text } \\
\text { Author } \\
\text { Additional details } \\
\text { Educational interest }\end{array}$ & Yes \\
\hline$V 11$ & Picture book & Affection, friendship & $\begin{array}{l}\text { Content } \\
\text { Illustration technique } \\
\text { Author / illustrator } \\
\text { Educational interest }\end{array}$ & No \\
\hline$V 12$ & $\begin{array}{l}\text { Picture book / } \\
\text { Interactive } \\
\text { book }\end{array}$ & Colours, art, and craft & $\begin{array}{l}\text { Content } \\
\text { Author / illustrator } \\
\text { Educational interest }\end{array}$ & Yes \\
\hline
\end{tabular}




\section{Students' Perception}

Regarding learning outcomes (Figure 4), most students considered that they had learned how to make a book review and to select and evaluate suitable texts for early-years education (77\%), as well as to use mobile video editing applications (76\%). A slightly smaller number thought that the activity enabled them to apply the knowledge they had acquired in the course about children's literature and/or encouraging children to read $(69 \%)$ and to get to know new literary texts suitable for early-years education (61\%). Sixty-two percent noticed a considerable or satisfactory improvement in digital competence, while 61 percent considered that they had discovered some educational applications for mobile devices and acquired some training in $\mathrm{m}$ learning. Slightly more than half (54\%) claimed to have developed their creative skills and teamwork considerably or satisfactorily. In contrast, only a small number believed that they had made considerable or satisfactory progress in oral expression $(31 \%)$ or written expression $(38 \%)$, although other students did admit to a slight improvement (54\% and 38\% respectively).

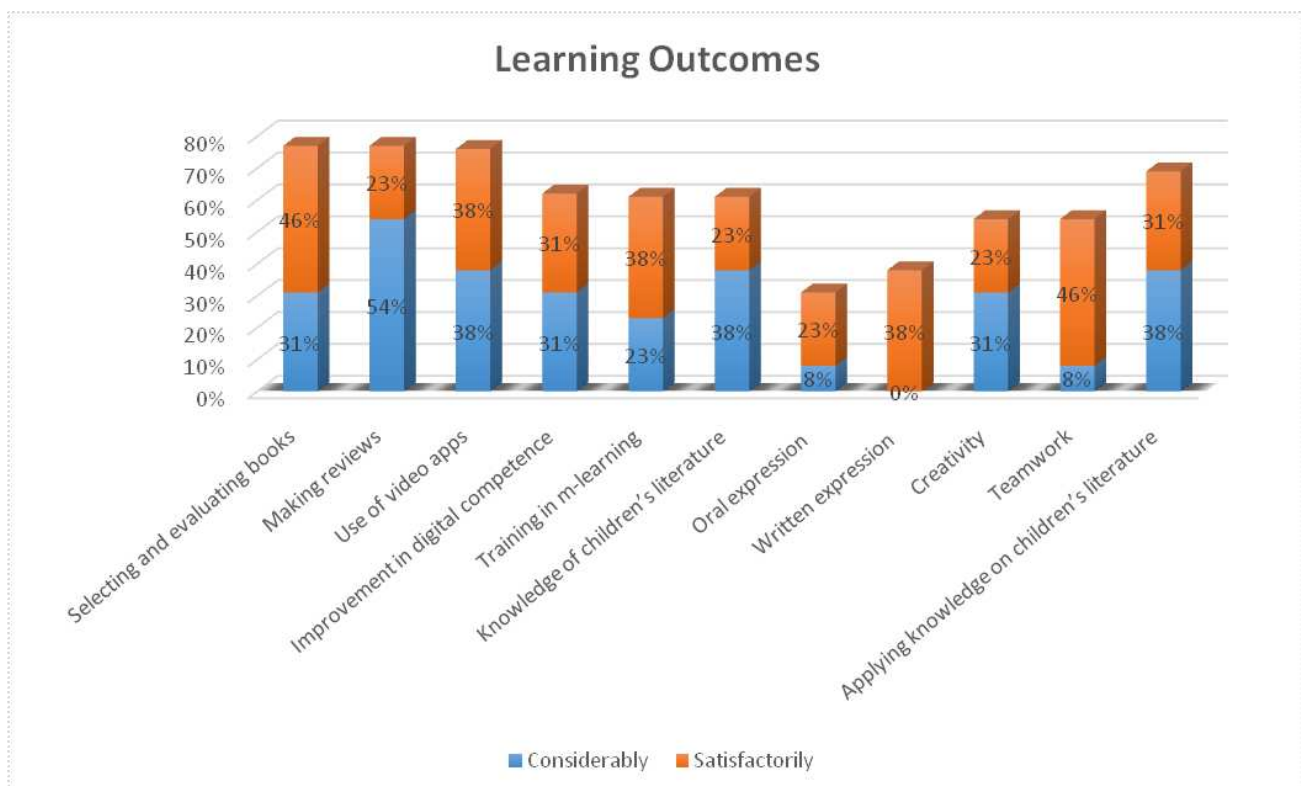

Figure 4: Learning to Which the Project Contributed Considerably or Satisfactorily According to Students' Perception Source: Neira-Piñeiro 2018

Regarding difficulties encountered, the most complex aspect was the oral presentation, which was found to be quite difficult by 38 percent of participants. This was followed by technical considerations (very or quite difficult for $23 \%$ ). The simplest activities were deemed to be the writing of the review and the choice of book. Even so, writing the text was perceived as moderately difficult by 31 percent. 
Table 4: Degree of Difficulty

\begin{tabular}{|l|l|l|l|l|l|}
\hline Aspects involved & Difficulty & \multicolumn{5}{l|}{} \\
\hline & None & Little & Some & Quite a lot & A lot \\
\hline Choice of book & $46 \%$ & $38 \%$ & $15 \%$ & $0 \%$ & $0 \%$ \\
\hline Writing the review & $0 \%$ & $62 \%$ & $31 \%$ & $8 \%$ & $0 \%$ \\
\hline Oral presentation & $15 \%$ & $23 \%$ & $23 \%$ & $38 \%$ & $0 \%$ \\
\hline Technical aspects & $15 \%$ & $23 \%$ & $38 \%$ & $15 \%$ & $8 \%$ \\
\hline
\end{tabular}

Source: Neira-Piñeiro 2018

Regarding the blog, 54 percent watched at least half of the videos published, 23 percent watched all or nearly all, and a further 23 percent watched only a few or none. Concerning the decision not to share videos on YouTube, the main reasons offered were the fact that it was not mandatory $(33 \%)$ or reluctance to appear on the internet $(33 \%)$. When evaluating the videos, the majority $(69 \%)$ claimed that they were quite or very pleased with their work, 23 percent were fairly satisfied, and only 8 percent were critical of their own work.

Bearing in mind the level of interest raised and the learning outcomes, the project scored 3.8 out of 5 and was evaluated as good or very good by 61 percent and average by the remaining 38 percent. Sixty-nine percent stated that they had enjoyed making the video review a lot or quite a lot and had found it interesting to watch those of their peers. Sixty-one percent reported that they had discovered new applications for mobile devices and slightly more than half (54\%) stated that they had found educational potential with mobile devices. To a lesser extent, a limited number of individuals were more critical, complaining about the time and effort involved in the out of class work. However, the general attitude toward m-learning was quite positive in the majority of those taking part in the survey, as 77 percent considered that the mobile resources used could be applied in a variety of ways to the early years classroom and 76 percent were in near or total agreement with carrying out this kind of task in university education.

\section{Instructor's Perception}

According to the instructor's own perception, the project contributed to a high degree to learning how to select and evaluate children's books, to be able to make a book review, and to apply the knowledge acquired during the course. It also familiarised students with some of the educational applications for mobile devices-including some video apps-and fostered creativity, collaborative learning skills, and written expression. To a lesser extent, students increased their oral communicative skills, their knowledge of children's literature and their digital competence in general.

More generally speaking, the instructor described herself as being quite satisfied with the project and perceived that students evidenced a good degree of engagement, as most showed interest and effort in doing the tasks required. However, a few did show some stress deriving from certain technical problems and the volume of work required to accomplish the task. From the point of view of the lecturer, the main strengths of the project were the advantages of BYOD, the opportunity to put into practice the learning acquired during the course, the development of communicative competence (oral and written) in a real context, and the contribution to fostering teamwork skills, creativity, autonomy, decision-making, and digital competence. The instructor also pointed out that students became familiar with the use of m-learning in literary education in a practical way, experiencing for themselves both the advantages and disadvantages of mobile resources.

However, the lecturer perceived some weaknesses; namely, in terms of the time and effort required to carry out the task and the technical problems experienced by some students. The 
project also involved a large amount of work for the instructor, as it was necessary to devote outof-class time to carefully planning the task, revising the scripts, providing feedback to the students, and, finally, to accessing the blog to watch students' videos. Furthermore, the instructor was not completely satisfied with the final stage, as greater use of and participation in the blog were needed. She suggested that the project could be improved by allowing more time to explore the video apps and paying more attention to the oral dimension of the task - for instance, by practicing and improving oral discourse in class before the final recording. The instructor also suggested that the educational possibilities offered by m-learning should be highlighted to students, making the application of this educational technology to the students' future professional activity more visible, particularly in the field of literary education.

\section{Discussion and Conclusions}

In the light of these results, the project was successful in adapting m-learning to literary education in the context of preservice early years teacher training. From a general perspective, the project helped to initiate students in m-learning, making them familiar with the use of video editing applications and with some of the educational possibilities of mobile technologies. Given that these are part of their daily lives, students had no qualms in making use of their own devices. Thus, m-learning combined with the BYOD (Bring Your Own Device) model enabled a task to be carried out easily which would otherwise have required the mobilization of a large number of technological resources not readily available in our context. Most students were favourably disposed toward the use of mobile devices in university education and showed both interest and effort during the process. Furthermore, we observed certain benefits indicated by other authors; primarily, the presentation of mobile pedagogy as a model, the creation of personalized learning experiences, social interaction and collaborative knowledge construction (Baran 2014), and the relevance of m-learning when carrying out collaborative tasks in the classroom (Miangah and Nezarat 2012). The task also allowed for the development of multiple skills: critical thinking, analysis and synthesis, the ability to work in teams, autonomy, decision-taking, creativity, and information retrieval skills, which form part of the transversal competences of this degree and which are key to students' future profession.

General findings are in consonance with the literature regarding the positive attitude of students toward the use of mobile devices (Ramos, Herrera, and Ramírez 2010); the adequacy of this educational technology for hybrid teaching when combining both in class and out-of-class activities as in this case (Delgado 2014); the suitability of m-learning for a student-centered teaching methodology (Delgado 2014), as well as for social and cooperative learning (Brazuelo and Gallego 2011); and the development of creative tasks (Sevillano 2013). The project also confirmed the flexibility of m-learning (Fombona and Pascual 2013; Iqbal and Bhatti 2017); in this case, it proved to be a versatile educational technology, easily adaptable to the context of literary education in an undergraduate teacher training degree.

However, the original contribution of this project refers to the application of m-learning to the literary education of future teachers. From this point of view, the audiovisual product was aimed at training in the teaching of literature, in the context of the teacher's role as literary mediator and expert in children's literature. Analysis of the videos revealed that the students had searched the internet for information about the authors and chosen works and carried out a reasoned analysis and evaluation of the literary texts selected, justifying the relevance of their choice. Therefore, the task provided an opportunity to apply the knowledge they had acquired in the course on children's literature regarding appropriate works for early-years education, illustration analysis, criteria for selecting reading material, and analysis of children's picturebooks and story books. In their evaluations, students coincided in highlighting the literary knowledge acquired concerning how to make a review, how to select and assess reading materials, knowledge of children's literature, and, in general, the connection with the content of the course. The instructor also highlighted learning results that were more directly related to the 
course on children's literature, so it is clear that m-learning was specifically adapted to the literary education of future teachers.

Furthermore, mobile technology combined with the internet enabled students to carry out an authentic communicative task that was meaningful and also required adaptation to purpose and audience, as recommended in the communicative approach in language teaching (Littlewood 2010). The creation of content was in line with constructivism whilst publication of the message created (Phase V) was related to the social dimension of m-learning (Low 2006). It was also consistent with the current approach for teaching literature and promoting reading, which adopts the communicative model and includes sharing and recommending books amongst peers (Margallo and Mata 2015; Munita 2017). If compared with more traditional ways of reviewing or analyzing books (such as discussing these in class or writing an in-paper-review), internet media and m-learning provided a wide and authentic audience and reproduced real activities that young readers do on the web, using their mobile devices.

Regarding the development of communicative abilities, the students tried to seek a variety of expressive elements with which to transmit and enhance the message. Although the task required expression through different languages (verbal, visual, musical), this aspect was not emphasized and students only perceived moderate progress in their communicative skills. More attention was given to written communication, whereas oral skills were not specifically trained, even though they were involved in the video production. Furthermore, students had more difficulty with the oral presentation than with script writing, so it is evident that more attention and scaffolding are required in guiding the oral part of the task. In contrast, attention was drawn to development in creativity, fostered by the degree of freedom given to the teams in the design of their video review and teamwork.

However, certain weaknesses were detected. Firstly, time was an issue, most significantly regarding the recording and editing process, which entailed a large amount of out-of-class work. Secondly, some groups had technical problems with applications, which did not prevent task achievement. Moreover, difficulties were also encountered in the production of oral discourse. Finally, although the Moodle platform allowed the videos to be shared, not all students viewed their classmates' reviews, which caused the final stage of the project to be less than satisfactory according to the instructor's perception.

Regarding the first issue mentioned, tasks such as this have proved to be extremely timeconsuming when carried out adequately. Furthermore, despite the appropriateness of m-learning for off-site learning, students appeared to prefer to carry out the collaborative tasks in class and were reluctant to engage in a disproportionate amount of out-of-class work. While the project had been carried out according to a model of hybrid learning, we recommend allowing more in-class time to enable students to become familiar with the applications, receive teacher support and finish editing in class time, and reducing the number of out-of-class activities to finding a suitable book, recording and publishing online. Due to the difficulties encountered by students with oral discourse, a specific session to prepare and practise this under instructor supervision is strongly recommended. Indeed, we deemed it important to provide guidelines for the control of oral discourse, focusing on paralinguistic codes of the voice and non-verbal language. Finally, to make better use of the social dimension of mobile learning (Low 2006; Torres, Infante, and Torre 2015), it is essential to find ways to incentivize interaction and consolidate the communicative dimension of the task, as social interaction commonly linked to mobile devices does not come automatically when carrying out a m-learning experience. In this respect, Gallardo, Marqués, and Bullen (2015) suggest that university students prefer to communicate with their peers via WhatsApp and Facebook rather than using Moodle, which is more closely linked to academic work and communication with the teacher, in the light of which we might consider the use of another medium for the dissemination of videos. Alternatively, accessing the blog could be made mandatory and mechanisms could be put into force such as the obligation to evaluate participation in the blog, by, for example, posting comments. 
To conclude, regarding the research questions, it appears that m-learning combined with BYOD can be successfully adapted to higher education. Creating a video review with mobile devices is a powerful activity for the literary training of undergraduate teachers, in line with current approaches in literature teaching, and involves the application of multiple knowledges and abilities related to literary education, communicative skills, decision-making, critical reasoning, teamwork skills, creativity, digital competence, etc., which are essential for future teachers. In the context of literary education of future teachers, it allows the development of creative tasks, which foster the critical analysis of children's books, promote the acquisition of skills and knowledge related to children's literature and its use in the classroom, and allows students to express and share their response to literature. Although m-learning based projects require time and effort, as well as instructor support and guidance, they offer multiple advantages, particularly versatility and adequacy for carrying out creative and collaborative tasks, as well as their contribution to the development of multiple skills.

\section{Limitations and Further Work}

This research project is constrained by the inherent limitations of a case study. However, due to the scarcity of research on m-learning projects in the literary education of undergraduate teachers, the analysis of this case can help to understand the main advantages and disadvantages of such educational technology as well as to suggest new ways to implement mobile learning in higher education. Furthermore, the conclusions drawn from the analysis of results could support further innovation in this field.

In the future, further research is needed into m-learning in literary education to gain a deeper insight into the benefits, affordances and impediments. Similarly, repeating the project while addressing the weak points mentioned above would allow changes to be made in methodology and observation of the effectivity of such changes. Thus, this research could be extended by means of a comparison with other similar cases. To conclude, we propose that other audiovisual activities using m-learning should be explored, in which the emphasis should be on creativity (adaptation or creation of children's stories), oral communication (oral narration), or the audiovisual exploration of diverse literary genres (video poems or children's theatre).

\section{Acknowledgement}

This work is part of a project on innovation in teaching, entitled "Oral Communication and mLearning: Photo and Video as a Resource in Teacher Training," and supported by the University of Oviedo (Spain).

\section{REFERENCES}

Al-Emran, Mostafa, Hatem M. Elsherif, and Khaled Shaalan. 2016. "Investigating Attitudes Towards the Use of Mobile Learning in Higher Education." Computers in Human Behaviour 56 (March): 93-102 . http://doi.org/10.1016/j.chb.2015.11.033.

Ally, Mohamed, and Josep Prieto Blázquez. 2014. "What Is the Future of Mobile Learning in Education?" RUSC 11 (1): 142-51. http://doi.org/10.7238/rusc.v11i1.2033.

Ambròs, Alba. 2014. "Proyecto Kuentalibros: Creación de Hipertextos Literarios Audiovisuales" [Kuentalibros Project: Creation of Literary Audiovisual Hypertexts]. In La Educación Literaria y la E-Literatura desde la Minificción [Literary education and E-Literature in Minifiction], edited by Osvaldo Cleger and José Manuel de Amo, 378-88. Barcelona: CE/Universitat de Barcelona. 
ANECA. 2005. Libro blanco. Título de Grado en Magisterio [White Book: Degree in Teaching]. Vol. 1. Madrid: ANECA.

Baran, Evrim. 2014. "A Review of Research on Mobile Learning in Teacher Education." Educational Technology and Society 17 (4): 17-32.

Bisquerra, Rafael, ed. 2004. Metodología de la Investigación Educativa [Educational Research Methodology]. Madrid: La Muralla.

Brazuelo, Francisco, and Domingo José Gallego. 2011. Mobile Learning: Los Dispositivos Móviles como Recurso Educativo [Mobile Learning: Mobile Devices as an Educational Resource]. Seville: MAD.

Burden, Kevin and Paul Hopkins. 2016. "Barriers and Challenges Facing Pre-Service Teachers' Use of Mobile Technologies for Teaching and Learning International." Journal of Mobile and Blended Learning 8 (2): 1-20. http://doi.org/10.4018/IJMBL.2016040101.

Caro-Valverde, María Teresa. 2015. "Recursos TIC para la Educación Literaria" [ICT Resources for Literary Education]. In Didáctica de la Lengua y Educación Literaria [Teaching Language and Literature], edited by Pedro Guerrero-Ruiz and María Teresa CaroValverde, 431-54. Madrid: Pirámide.

Castaño, Carlos, and Julio Cabero, eds. 2013. Enseñar y Aprender en Entornos Mlearning [Teaching and Learning in Mlearning Environments]. Madrid: Síntesis.

Chen, Baiyn, Ryan Seilhamer, Luke Bennett, and Sue Bauer. 2015. "Students' Mobile Learning Practices in Higher Education." Educause Review, June 22. https://er.educause.edu /articles/2015/6/students-mobile-learning-practices-in-higher-education-a-multiyear -study.

Cohen, Louis, Lawrence Manion, and Keith Morrison. 2005. Research Methods in Education. London: Routledge.

Crescente, M. Louise, and Doris Lee. 2011. "Critical Issues of M-Learning: Design Models, Adoption Processes, and Future Trends." Journal of the Chinese Institute of Industrial Engineers 28 (2): 111-23.

Delgado, Francisco Javier. 2014. “Actualización Docente en Tecnologías Educativas y Aprendizaje Móvil: Desarrollo de un Programa Institucional" [Professional Training in Educational Technology and Mobile Learning: Development of an Institutional Program]. Revista de Formación e Innovación Educativa Universitaria [Journal of University Educational Training and Innovation] 7 (4): 211-26.

Ekanayake Sakunthala and Jocelyn Wishart. 2015. "Integrating Mobile Phones into Teaching and Learning: A Case Study of Teacher Training Through Professional Development Workshops." British Journal of Educational Technology 46 (1): 173-89. http://doi.org/10.1111/bjet.

Fernández-Molina, Milagros, Victoria González and Gemma Del-Molino. 2011. "Perfil del alumnado universitario de Educación Infantil" [Profile of University Students of the Degree of Preschool Education]. Revista de Investigación Educativa [Journal of Educational Research] 29 (1): 187-203.

Fombona Javier and Ángeles Pascual. 2013. "Beneficios del M-Learning en la Educación Superior" [Benefits of M-Learning in Higher Education]. Educatio Siglo XXI [Education 21st Century] 31 (2): 211-34.

Gallardo, Elena, Luis Marqués and Mark Bullen. 2015. "Students in Higher Education: Social and Academic Uses of Digital Technology." RUSC 12 (1): 25-37. http://doi.org/10.7238/rusc.v12i1.2078.

García Riaza, Blanca, and Ana Iglesias Rodríguez. 2016. "Students' Perception of the Integration of Mobile Devices as Learning Tools in Pre-Primary and Primary Teacher Training Degrees." International Journal of Human Capital and Information Technology Professionals 7 (2): 19-35 http://dx.doi.org/10.4018/IJHCITP.2016040102. 
Giráldez, Andrea, ed. 2015. De los Ordenadores a los Dispositivos Móviles. Propuestas de Creación Musical y Audiovisual [From Computers to Mobile Devices: Proposals for Musical and Audiovisual Creation]. Barcelona: Graó.

Gros, Begoña. 2013. "Aplicaciones Móviles para la Educación” [Mobile Apps for Education]. In Tecnologías y Medios para la Educación en la E-Sociedad [Technologies and Media for Education in E-Society], edited by J. Ignacio Aguaded and Julio Cabero, 71-89. Madrid: Alianza.

Harland, Tony. 2014. "Learning about Case Study Methodology to Research Higher Education." Higher Education Research and Development 33 (6): 1113-22. http://doi.org/10.1080/07294360.2014.911253.

Herrington, Anthony, and Jan Herrington. 2006. "Identifying Authentic Mobile Learning in Teacher Education: A Design-Based Approach." Paper presented at the IADIS International Conference Mobile Learning, Dublin, Ireland, July 14-16, 2006.

Iqbal, Shakeeland, and Zeeshan Ahmed Bhatti. 2017. "What Drives M-Learning? An Empirical Investigation of University Student Perceptions in Pakistan." Higher Education Research and Development $36 \quad$ (4): 730-46. http://doi.org/10.1080/07294360.2016.1236782.

Ireri, Bonface Ngari, Ruth Diko Wario, and Irene Mukiri Mwingirwa. 2018. "Choosing and Adapting a Mobile Learning Model for Teacher Education." In Handbook of Research on Digital Content, Mobile Learning, and Technology Integration Models in Teacher Education, edited by Jared Keengwe, 132-48. Hershey, PA: ISI Global.

Johnson, Larry, Alan Levine, Rachel Smith, and Sonja Stone. 2010. The 2010 Horizon Report. Austin: The New Media Consortium.

Johnson, Larry, Samantha Adams, Michele Cummins, Victoria Estrada, Alex Freeman, and Courtney Hall. 2016. The Horizon Report: 2016: Higher Education Edition. Austin: The New Media Consortium.

Kukulska-Hulme, Agnes. 2009. “Will Mobile Learning Change Language Learning?" ReCALL 21 (2): 157-65. http://doi.org/10.1017/S0958344009000202.

Littlewood, William. 2010. Communicative Language Teaching. Cambridge: Cambridge University Press.

Lluch, Gemma, and Felipe Zayas. 2015. Leer en el centro escolar [Reading in the School]. Barcelona: Octaedro.

Low, Leonard. 2006. "Connections: Social and Mobile Tools for Enhancing Learning." The Knowledge Tree Journal 12: 1-10. http://robertoigarza.files.wordpress.com/2008/10/art -social-and-mobile-tools-for-enhancing-learning-low-2006.pdf.

Luque-Agulló, Gloria, and Natividad Martos-Vallejo. 2015. "Mobile Learning in the Foreign Language Classroom." Huarte de San Juan 15: 79-103.

Margallo, Ana María and Juan Mata. 2015. "La lectura: práctica social y formación escolar" [Reading: Social Practice and School Training]. In Didáctica de la lengua y la literatura [Teaching Language and Literature], edited by Juan Mata, Pilar Núñez, and José Rienda, 179-202. Madrid: Pirámide.

Miangah, Tayebeh Mosavi, and Amin Nezarat. 2012. "Mobile-Assisted Language Learning." International Journal of Distributed and Parallel Systems 3 (1): 309-19. http://doi.org/10.5121/ijdps.2012.3126.

Munita, Felipe. 2017. "La didáctica de la literatura: hacia la consolidación del campo" [Teaching Liteature: Toward the Consolidation of the Field]. Educação e Pesquisa [Education and Research] 43 (2): 379-92. http://doi.org/10.1590/S1517-9702201612151751.

Nguyen, Lemai, Siew Mee Barton, and Linh Thuy Nguyen. 2015. "iPads in Higher Education." British Journal of Educational Technology 46 (1): 190-203. http://doi.org/10.1111/bjet.12137. 
Norman, K. Denzin, and Yvonna S. Lincoln, eds. 1994. Handbook of Qualitative Research. London: SAGE Publications.

Ozdamli, Fezile. 2012. "Pedagogical Framework of M-Learning." Procedia: Social and Behavioral Sciences 31: 927-31.

Ramos, Ana Isabel, José Alberto Herrera, and María Soledad Ramírez. 2010. "Desarrollo de Habilidades Cognitivas con Aprendizaje Móvil: un Estudio de Casos". [Developing Cognitive Skills with Mobile Learning: A Case Study]. Comunicar 34 (XVII): 201-209. http://doi.org/10.3916/C34-2010-03-20

Rovira-Collado, José. 2017. "Booktrailer y Booktuber como Herramientas LIJ 2.0 para el Desarrollo del Hábito Lector" [Booktrailer and Booktuber as Children's and Young Adult Literature 2.0 Tools for Reading Promotion]. Investigaciones sobre Lectura [Research on Reading] 7: 55-72.

Sevillano, María Luisa. 2013. "Enseñanza y aprendizaje con dispositivos móviles" [Teaching and Learning with Mobile Devices]. In Tecnologías y Medios para la Educación en la ESociedad [Technologies and Media for Education in E-Society], edited by J. Ignacio Aguaded and Julio Cabero, 159-84. Madrid: Alianza.

Sevillano, María Luisa, and Esteban Vázquez-Cano. 2015. "The Impact of Digital Mobile Devices in Higher Education.” Educational Technology and Society 18 (1): 106-18.

Sung, Yao-Ting, Kuo-En Chang, and Tzu-Chien Liu 2016. "The Effects of Integrating Mobile Devices with Teaching and Learning on Students' Learning Performance: A MetaAnalysis and Research Synthesis". Computers \& Education 94: 252-75. http://doi.org/10.1016/j.compedu.2015.11.008.

Torres, Juan Carlos, Alfonso Infante, and Pablo Vicente Torres. 2015. “Aprendizaje Móvil: Perspectivas" [Mobile Learning: Perspectives]. RUSC 12 (1): 38-49. http://doi.org/10.7238/rusc.v12i1.1944.

Trujillo, Fernando. 2015. "De los ordenadores a los dispositivos móviles" [From Computers to Mobile Devices]. In De los Ordenadores a los Dispositivos Móviles. Propuestas de Creación Musical y Audiovisual [From Computers to Mobile Devices: Proposals for Musical and Audiovisual Creation], edited by Andrea Giráldez, 11-47. Barcelona: Graó.

Shohel, M. Mahruf C., and Tom Power. 2010. "Introducing Mobile Technology for Enhancing Teaching and Learning in Bangladesh: Teacher Perspectives." Open Learning 25 (3): 201-15. http://doi.org/10.1080/02680513.2010.511953.

Vázquez-Cano, Esteban. 2014. "Mobile Distance Learning with Smartphones and Apps in Higher Education." Educational Sciences: Theory and Practice 14 (4): 1505-20.

$\mathrm{Wu}$, Wen-Hsiung, Yen-Chun Jim Wu, Chun-Yu Chen, Hao-Yun Kao, Che-Hung Lin and SihHan Huang. 2012. "Review of Trends from Mobile Learning Studies: A MetaAnalysis." Computers and Education 59: 817-27. http://doi.org/10.1016/j.compedu.2012.03.016.

\section{ABOUT THE AUTHOR}

María del Rosario Neira-Piñeiro: Lecturer, Department of Education, University of Oviedo, Oviedo, Spain 


\section{The International Journal of Learning in Higher}

Education is one of ten thematically focused journals in the collection of journals that support The Learner Research Network -its journals, book series, conference, and online community.

The journal offers studies of learning at college and university levels, including teacher education.

As well as articles of a traditional scholarly type, this journal invites presentations of practice-including documentation of higher education practices and exegeses of the effects of those practices.

The International Journal of Learning in Higher Education is a peer-reviewed, scholarly journal. 